\title{
PENINGKATAN INTERPROFESSIONAL COLLABORATION DALAM MENJALANKAN PROGRAM KESELAMATAN PASIEN
}

\author{
Erta Iman Jelita Harefa/181101138
}

ertahrf08@gmail.com

\begin{abstract}
Abstrak
Latar belakang: Di era kemajuan ilmu kesehatan saat ini, Peningkatan permasalahan pasien yang kompleks membutuhkan keterampilan dan pengetahuan dari beberapa tenaga profesional. Oleh karena itu kerjasama dan kolaborasi yang baik antar profesi kesehatan sangat dibutuhkan untuk meningkatkan kepuasan pasien dalam melakukan pelayanan kesehatan. Pelayanan kesehatan yang diberikan di rumah sakit dilakukan oleh berbagai profesi tenaga kesehatan.

Tujuan: Penulisan ini bertujuan untuk mengetahui dan memberi informasi tentang peningkatan interprofessional collaboration dalam menjalankan program keselamatan pasien.

Metode: Penulisan ini menggunakan metode literature review dengan pendekatan jurnal atau artikel, buku dan e-book yang relevan dan akurat serta berfokus pada peningkatan interprofessional collaboration dalam menjalankan program keselamatan pasien dengan menggunakan Google Scholar, Portal Garuda, dan Jurnal Keperawatan Indonesia.

Hasil: Berdasarkan hasil pencarian literatur terdapat beberapa program keselamatan pasien yang terdiri dari: membangun budaya keselamatan pasien, menjalankan standar keselamatan pasien, melaksanakan sasaran keselamatan pasien, melaksanakan sistem pelaporan dan membentuk organisasi.

Pembahasan: Kolaborasi Interprofesi atau Interprofessional Collaboration (IPC) adalah kemitraan antara orang dengan latar belakang profesi yang berbeda dan bekerja sama untuk memecahkan masalah kesehatan dan menyediakan pelayanan kesehatan. Menurut WHO, IPC terjadi saat berbagai profesi kesehatan bekerja sama dengan pasien, keluarg dan komunitas untuk menyediakan pelayanan komprehensif dan berkualitas tinggi.

Penutup: IPC adalah wadah dalam menjalin kebersamaan dan kekompakkan dalam memberikan mutu pelayanan kesehatan lebih optimal.
\end{abstract}

Kata kunci: interprofessional collaboration, program, keselamatan pasien 


\section{LATAR BELAKANG}

Di era kemajuan ilmu kesehatan saat ini, pendidikan merupakan suatu hal yang penting dalam mengembangkan kualitas pelayanan kesehatan, berdasarkan hal tersebut maka untuk menyesuaikan kebutuhan masyarakat perlunya sistem pendidikan yang bermutu dan mempunyai orientasi pada ilmu pengetahuan yang berkembang pesat saat ini (Febriyani, 2014). Peningkatan permasalahan pasien yang kompleks membutuhkan keterampilan dan pengetahuan dari beberapa tenaga profesional. Oleh karena itu kerjasama dan kolaborasi yang baik antar profesi kesehatan sangat dibutuhkan untuk meningkatkan kepuasan pasien dalam melakukan pelayanan kesehatan.

Pelayanan kesehatan yang diberikan di rumah sakit dilakukan oleh berbagai profesi tenaga kesehatan. Berbagai profesi yang terlibat dalam pelayanan kesehatan terdiri dari tenaga medis, tenaga psikologis klinis, tenaga keperawatan, tenaga kebidanan, tenaga kefarmasian,tenaga gizi, tenaga keterapian fisik, tenaga keteknisian medis dan teknik biomedika (UndangUndang No.36 Tahun 2014).

Pelayanan kesehatan di rumah sakit merupakan pelayanan dari berbagai profesi kesehatan yang berkolaborasi untuk mengoptimalkan pelayanan kesehatan (Sitorus, 2006). Institute of Medicine (IOM) dan World Health Organization (WHO) meminta tenaga kesehatan profesional untuk bekerja sama dalam Interprofessional Collaboration (IPC) untuk meningkatkan pelayanan kesehatan (IOM, 2010).

Pendekatan kolaborasi yang masih berkembang saat ini adalah Interprofessional Collaboration (IPC) sebagai wadah dalam upaya mewujudkan praktik kolaborasi yang efektif antar profesi.

Tenaga kesehatan harus melakukan praktek kolaborasi dengan baik dan tidak melaksanakan pelayanan kesehatan sendiri-sendiri. Praktek kolaborasi dapat menurunkan angka komplikasi, lama rawat di rumah sakit, konflik diantara tim kesehatan, dan tingkat kematian serta di bidang kesehatan mental, praktek kolaboratif dapat meningkatkan kepuasan pasien dan tim kesehatan, mengurangi durasi pengobatan, mengurangi biaya perawatan, mengurangi insiden bunuh diri, dan mengurangi kunjungan rawat jalan.

Praktek kolaborasi dapat dilakukan dengan menjalankan program khususnya 
dalam keselamatan pasien. Tindakan kolaborasi sangat diperlukan untuk menunjang peningkatan mutu pelayanan. Dalam menjalankan program keselamatan pasien diperlukan tindakan kolaborasi dari berbagai tenaga kesehatan yang ada di rumah sakit.

\section{TUJUAN}

Tujuan penulisan ini adalah untuk mengetahui dan memberi informasi tentang peningkatan interprofessional collaboration dalam menjalankan program keselamatan pasien.

\section{METODE}

Penulisan ini menggunakan metode literature review dengan pendekatan jurnal atau artikel, buku dan e-book yang relevan dan akurat serta berfokus pada peningkatan interprofessional collaboration dalam menjalankan program keselamatan pasien. Adapun jurnal atau artikel dan e-book yang digunakan pada literature review adalah jurnal atau artikel dan e-book yang didapatkan dengan menggunakan Google Scholar, Portal Garuda, dan Jurnal Keperawatan Indonesia.

\section{HASIL}

Berdasarkan hasil pencarian literatur di dapatkan beberapa program keselamatan pasien sebagai berikut:

1. Membangun Budaya Keselamatan di Rumah Sakit yang terdiri dari:

- Safe culture (perawatan budaya yang aman).

- Safe care (perawatan yang aman)

- Safe support system (sistem pendukung yang aman)

- Safe place (tempat yang aman).

2. Adapun beberapa program kesehatan berdasarkan permenkes Nomor 11 Tahun 2017 yang terdiri dari:

- Menjalankan standar keselamatan pasien.

- Melaksanakan sasaran keselamatan pasien.

- Menjalankan tujuh langkah keselamatan pasien.

3. Melakukan sistem pelaporan insiden yang terjadi di rumah sakit.

4. Membuat organisasi untuk melakukan pelatihan tentang keselamatan pasien. 


\section{PEMBAHASAN}

Interprofessional Collaboration (IPC) merupakan wadah kolaborasi efektif untuk meningkatkan pelayanan kesehatan kepada pasien yang didalamnya terdapat profesi tenaga kesehatan meliputi dokter, perawat, farmasi, ahli gizi, dan fisioterapi.

Kolaborasi Interprofesi atau Interprofessional Collaboration (IPC) adalah kemitraan antara orang dengan latar belakang profesi yang berbeda dan bekerja sama untuk memecahkan masalah kesehatan dan menyediakan pelayanan kesehatan. Menurut WHO, IPC terjadi saat berbagai profesi kesehatan bekerja sama dengan pasien, keluarg dan komunitas untuk menyediakan pelayanan komprehensif dan berkualitas tinggi.

Dalam melakukan peningkatan IPC untuk menjalankan program keselamatan pasien diperlukan hal utama yaitu peningkatan komunikasi yang efektif. Sehingga para tenaga kesehatan dapat melakukan tindakan pelayanan kesehatan yang aman dan efektif.

IPC ini menjadi hal yang penting bagi setiap tenaga kesehatan dikarenakan melalui metode ini semua tenaga kesehatan yang ada di rumah sakit dapat menjalin komunikasi yang baik dalam menyelesaikan setiap permasalahan pasien dan dapat menunjang penyembuhan kesehatan pasien.

\section{PENUTUP}

Peningkatan Interprofessional Collaboration (IPC) dalam menjalankan program keselamatan pasien sangatlah berguna dan penting sebab melalui metode atau cara ini dapat memberikan pelayanan kesehatan yang lebih baik.

IPC ini juga adalah wadah dalam menjalin kebersamaan dan kekompakkan dalam memberikan pelayanan kesehatan.

Berdasarkan hasil yang telah didapat bahwa IPC ini dapat terlaksana jika dilakukan secara bersama antar tenaga kesehatan.

\section{REFERENSI}

Al-asaf, A. F. (2013). Mutu Pelayanan Kesehatan: Perspektif Internasional. Jakarta: EGC.

Departemen Kesehatan RI. (2008). Panduan Nasional Keselamatan Pasien Rumah Sakit (Patient Safety). Jakarta: Depkes RI. 
Departemen Kesehatan RI. (2008). Upaya Peningkatan Mutu Pelayanan Rumah Sakit. Jakarta: Depkes RI.

Fatalina, F., Sunartini, dkk. (2015). Persepsi dan Penerimaan Interprofessional Collaboration Practice Bidang Maternitas Pada Tingkat Kesehatan. Jurnal PKI, 28-36.

Firawati, Pabuty, A., Putra, A. S. (2012). Pelaksanaan Program

Keselamatan Pasien di RUSD Solok. Jurnal Kesehatan Masyarakat, 74-78.

Ilmanita, D. (2014). Perbandingan Persepsi Mahasiswa Kesehatan Mengenai Keterlibatan Apoteker Dalam IPC Pada Mahasiswa Yang Sudah dan Belum Mendapat IPE. Jurnal Kesehatan, 1-11.

Lestari, Y., Saleh, A., dkk. (2017). Hubungan Interprofessional Collaboration Dengan Pelaksanaan Catatan Perkembangan Pasien Terintegrasi di RSUD Prof. Dr. H. M. Anwar Makkatutu Kabupaten Bantaeng, Vol.7 No.1 : 85-90.
Machmud, R. (2008). Manajemen Mutu Pelayanan Kesehatan. Jurnal Kesehatan Masyarakat, 186-190. Permenkes RI. (2017). Peraturan Menteri Kesehatan Republik Indonesia Nomor 11 Tahun 2017 Tentang Keselamatan Pasien. Jakarta: Depkes RI.

Ridar, I., Santoso, A. (2018). Peningkatan Komunikasi Dalam Pelaksanaan Interprofessional Collaboration Melalui Catatan Perkembangan Pasien Terintegrasi. Jurnal Keperawatan, 144-147.

Rokhmah, Noor Ariyani. (2017). Komunikasi Efektif Dalam Praktek Kolaborasi Interprofesi Sebagai Upaya Meningkatkan Kualitas Pelayanan. Journal of Health Studies, Vol. 1 No. 1 : 6571.

Simamora, R. H. (2019). Buku Ajar Pelaksanaan Identifikasi Pasien. Uwais Inspirasi Indonesia.

Simamora, R. H. (2019). Documentation of Patient Identification Into The Electronic System to Improve The Quality of Nursing Services. International Journal of Scientific \& Technology Research. 
Simamora, R. H. (2019). The Influence

of Training Handover Based SBAR Communication for Improving Patients Safety. Indian Journal of Public Health Research \& Development.

Sitorus, R. (2006). Model Praktik Keperawatan Professional di Rumah Sakit. Jakarta: EGC.

Triwibowo, C., Yuliawati, S., Husna, N. A. (2016). Handover Sebagai Upaya Peningkatan Keselamatan Pasien (Patient Safety) di Rumah Sakit. Jurnal Keperawatan Soedirman, 76-79.

Ulumiyah, Nurul H. (2018). Meningkatkan Mutu Pelayanan Kesehatan Dengan Penerapan Upaya Keselamatan Pasien di Puskesmas. Jurnal Administrasi Kesehatan Indonesia, 150-154. 